\title{
Durability of Fly Ash Based Geopolymer Concrete against Chloride and Sulphuric Acid Attack
}

\author{
${ }^{1}$ Kartika Ilma Pratiwi, currently pursuing Master Degree \\ Program in Civil Engineering, Sriwijaya University, \\ Indonesia
}

\begin{abstract}
The aim of this study was to replace Portland cement with fly ash-based geopolymer as precursors, to serve as a binder after reacting with $\mathrm{NaOH}$ and $\mathrm{Na}_{2} \mathrm{SiO}_{3}$ activators. The test object existed in the form of a cube of size $50 \times 50 \times 50 \mathrm{~mm}$. The mortar was treated for 28 days and then immersed in a sulfate solution at similar interval using the wet-dry cycle and non-cycle methods. The compressive strength of the geopolymer mortar was estimated as $45.90 \mathrm{MPa}$ before immersion. Therefore, 35.79 MPa, 41.09 MPa, as well as $37.85 \mathrm{MPa}$ were reported after submersion in the respective solutions of $5 \% \mathrm{H}_{2} \mathrm{SO}_{4}, \mathrm{Na}_{2} \mathrm{SO}_{4}$, and $\mathrm{NaCl}$, using wet-dry cycle. Based on the non-cycle approach, the resulting strength was 37.36 MPa, 43.05 MPa and 39.52 MPa correspondingly.
\end{abstract}

Keywords:- Geopolymer mortar, durability, acid solution, sulfate solution, chloride solution.

\section{INTRODUCTION}

Portland cement, comprising silica, alumina and lime, is the main material used as a binder in making concrete. These chemical compounds are created through combustion at temperatures above $1,000^{\circ} \mathrm{C}$, followed by the release of $\mathrm{CO}_{2}$. This is a leading cause of environmental pollution, hence, the need to replace Portland cement use with geopolymer alternatives [1].

The coal combustion process is known to generate abundant fly ash as waste materials, using electric steam power plants. These products are possibly used as substitutes for Portland cement, due to the similarity in particle size. In addition, the high $\mathrm{SiO}_{2}$ and $\mathrm{Al}_{2} \mathrm{O}_{3}$ content is implicated in geopolymer bonds. Joseph Davidovits introduced the term "Geopolymer" in 1978 to describe a mineral binder of varying chemical composition [2, 3]. These include the high silica ( $\mathrm{Si}$ ) and alumina (Al) content, present as the primary elements in natural form, which play an important role in the binding process.

Sanni and Khadiriaikar [4] used fly ash as a precursor in geopolymer concrete research. This was activated using sodium hydroxide and sodium silicate treated at $60^{\circ} \mathrm{C}$ for 24 hours. The treatment duration is capable of increasing the polymerization process, subsequently yielding products with higher compressive strength.

The synthesized geopolymers were evaluated to determine the durability under different aggressive chemical environments. For example, acidic, sulfuric and chloride

\author{
${ }^{2}$ Saloma, lecturer in Civil Engineering \\ Department in Sriwijaya University, Indonesia,
}

media were tested by comparing the effects of conventional concrete. Singh et al. [5] reported on the excellent acid resistant ability of fly ash-based geopolymer concrete (GPC) against sulfuric and chloride attack, compared to the conventional type (OPC).

Kumar et al. [6] analyzed the effect of chemical solutions on the behavior of geopolymer concrete. The results showed the acid to be stronger than the sulfate, evidenced by the smaller reduction value in compressive strength. Meanwhile, a value between both mix is observed with the chloride.

According to Wiyono et al. [7], durability is the main factor to consider during concrete production, therefore further research is needed to ensure improvement. The concrete specimen was exposed to diluted sulfuric acid to accelerate the damage process, through wet-dry cycle application. This paper discusses the resistance of fly ashbased geopolymer as a substitute for Portland cement in the manufacture of geopolymer mortar.

\section{MATERIAL}

The basic material used in the formation of geopolymer was fly ash, obtained from PT, Pupuk Sriwidjaja Palembang. Table 1 provides an outline of the chemical composition, based on the XRF test results. This showed the presence of high $\mathrm{SiO}_{2}$ and $\mathrm{Al}_{2} \mathrm{O}_{3}$ compounds, instigating the possible application as a geopolymer bond. In addition, the grains structure was observed using the Scanning Electron Microscopy (SEM), and the results are shown in Figure 1. Meanwhile, Figure 2 demonstrates the level of fly ash reactivity, obtained through XRD test. Figure 1 shows the Scanning Electron Microscope (SEM) test results of the fly ash, indicating the a dominant round shape with a maximum grain diameter of $\pm 50 \mu \mathrm{m}$. Figure 2 presents the result of XRD analysis, designating the amorphous characteristics as well as a high silica and alumina content. The concentration of $\mathrm{NaOH}$ solution used was $14 \mathrm{M}$ with a $\mathrm{Na}_{2} \mathrm{SiO}_{3} / \mathrm{NaOH}$ ratio of 2 . Specifically, $\mathrm{Na}_{2} \mathrm{SiO}_{3}$ was applied in mortar mixtures to improve the polymerization process, and also to ease the stirring process by serving as a superplasticizer at $5 \%$ of the fly ash content. However, dry materials as fine aggregate and fly ash are mixed for 3 minutes to increase homogeneity. Subsequently, the wet mixture is put into the dry material for 4 minutes [8], and curing is performed using the steam method at of $60^{\circ} \mathrm{C}$ for 24 hours. 


\begin{tabular}{|c|c|c|}
\hline No. & Chemical Compounds & Percentage (\%) \\
\hline 1. & Silicate $\left(\mathrm{SiO}_{2}\right)$ & 50.67 \\
\hline 2. & Alumina $\left(\mathrm{Al}_{2} \mathrm{O}_{3}\right)$ & 30.41 \\
\hline 3. & Iron Oxide $\left(\mathrm{Fe}_{2} \mathrm{O}_{3}\right)$ & 40.28 \\
\hline 4. & Lime $(\mathrm{CaO})$ & 4.12 \\
\hline 5. & Manganese $(\mathrm{MnO})$ & 0.06 \\
\hline 6. & Sodium $\left(\mathrm{Na}_{2} \mathrm{O}\right)$ & 4.88 \\
\hline 7. & Potassium $\left(\mathrm{K}_{2} \mathrm{O}\right)$ & 0.78 \\
\hline 8. & Phosphate $\left(\mathrm{P}_{2} \mathrm{O}_{5}\right)$ & 0.27 \\
\hline 9. & Titanium $\left(\mathrm{TiO}_{2}\right)$ & 0.81 \\
\hline 10. & Sulfur $\left(\mathrm{SO}_{3}\right)$ & 0.35 \\
\hline
\end{tabular}

Table 1:- Chemical Composition of Fly Ash

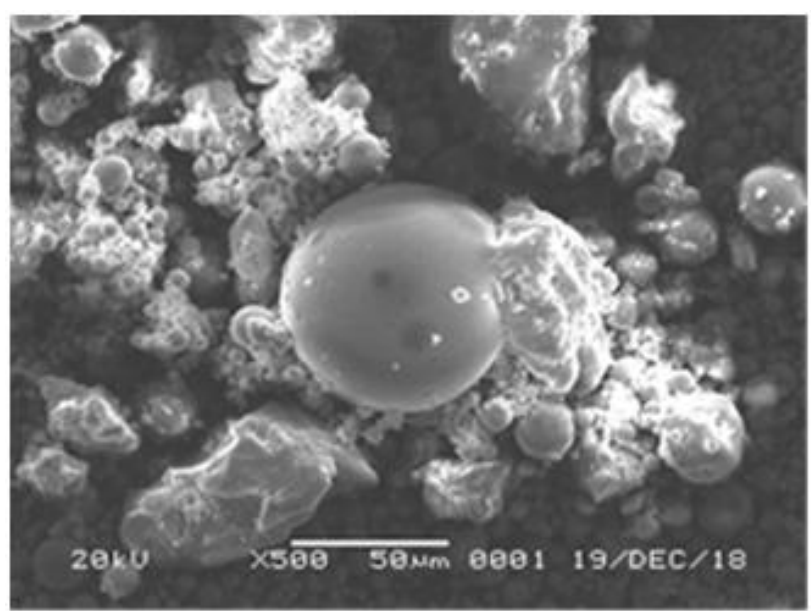

Fig 1:- SEM test results of fly ash.

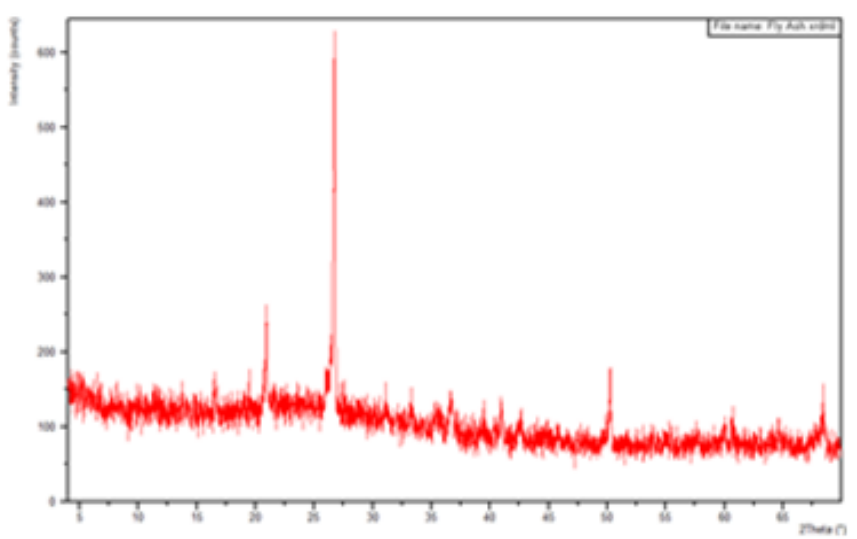

Fig 2:- XRD test results of fly ash.

\section{RESULTS AND DISCUSSION}

\section{A. Slump Flow and Setting Time}

Slump flow testing is carried out on a mixture of fresh mortar, and measured using a flow table. Figure 3 shows a slump flow diameter of $13.50 \mathrm{~cm}$, while the introduction of $14 \mathrm{M} \mathrm{NaOH}$ concentration influences the properties of fresh concrete produced, including the mortar mixture thickness. This leads to reduced workability, hence a smaller diameter is generated.

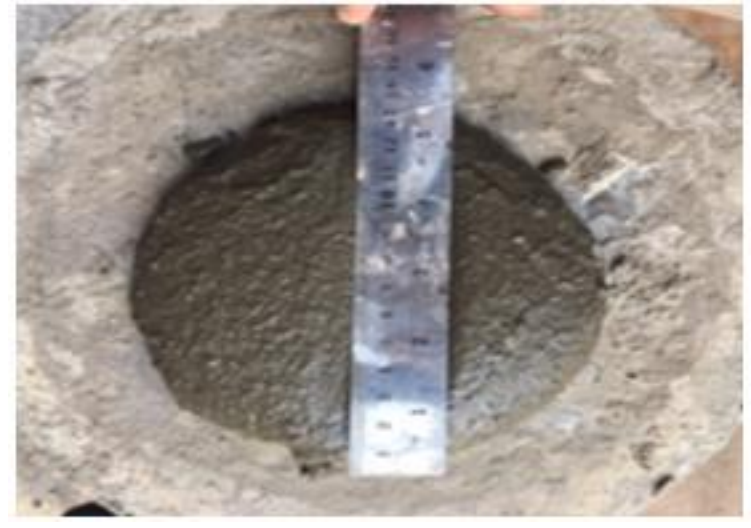

Fig 3:- Slump flow test

Figure 4 shows the time setting test using the Vicat needle. The results show the initial and final setting time on mortar with $14 \mathrm{M} \mathrm{NaOH}$ concentration as 66.43 and 105 minutes respectively. This outcome is relatively faster compared to the conventional mortar method, due to several influencing factors, including high alkaline solution ratio $\left(\mathrm{Na}_{2} \mathrm{SiO}_{3} / \mathrm{NaOH}\right)$ and large $\mathrm{NaOH}$ concentrations used in geopolymer mixtures. Furthermore, the fineness of the fly ash grains used is also an indicator while accelerating the setting time.

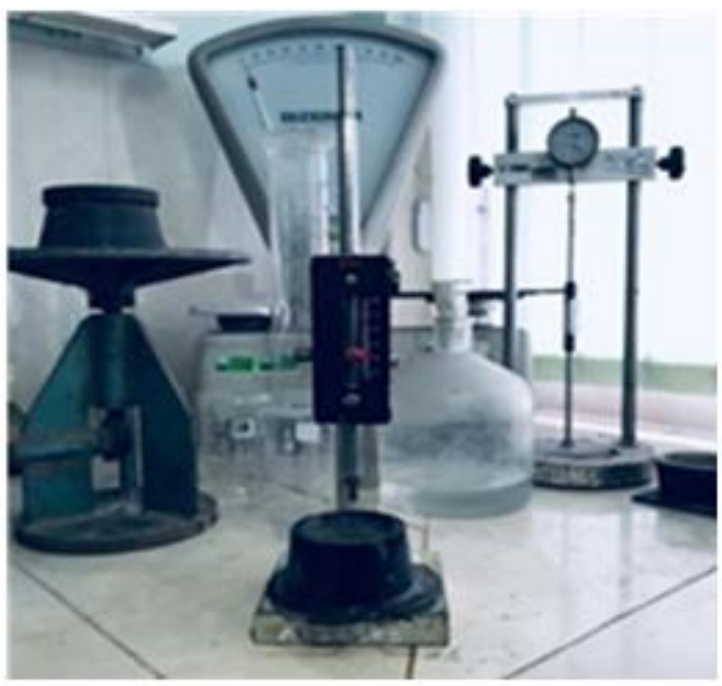

Fig 4:- Setting time.

\section{B. Decrease in Mass}

Geopolymer mortar cured for 28 days was weighed and immersed in sulfuric and chloride acid solution of 5\% similar to curing period. The aim of mortar immersion was to determine the decline in mass after exposure, as show in Figure 5. The percentage decrease in mass of mortar immersed in $\mathrm{H}_{2} \mathrm{SO}_{4}$ solution is greater compared to $\mathrm{Na}_{2} \mathrm{SO}_{4}$ and $\mathrm{NaCl}$ solutions using wet-dry cycle and non cycle methods. The drop resulted from the chemical reactions between the mortar and individual test solutions during the immersion process by the wet-dry non cycle method. Meanwhile, for wet-dry cycle approach, after immersion for a day, drying is then carried out also for additional one day. This caused a decline in the geopolymer motar components and structure. 


\section{Decrease in Compressive Strength}

Figure 6 shows the results of mortar compressive strength, and $45.90 \mathrm{MPa}$ was recorded - 28 days before being immersed. Subsequently, 35.79 $\mathrm{MPa}, 41.09 \mathrm{MPa}$ and $37.85 \mathrm{MPa}$ were measured by the wet-dry cycle method after soaking in $\mathrm{H}_{2} \mathrm{SO}_{4}, \mathrm{Na}_{2} \mathrm{SO}_{4}$ and $\mathrm{NaCl}$ respectively. Meanwhile, non cycle technique for the same set of solutions reflected 37.36 $\mathrm{MPa}, 43.05 \mathrm{MPa}$, and $39.52 \mathrm{MPa}$ respectively after submersion.

Furthermore, all mortars dipped in sulfate and chloride experienced degradation in strength as seen by the deposition of a white crystal layer on the surface, while samples immersed in $\mathrm{H}_{2} \mathrm{SO}_{4}$ showed the highest percentage strength reduction (Figure 7). The decrease in mass and compressive strength was as a result of the presence of active calcium hydroxide $\left(\mathrm{Ca}(\mathrm{OH})_{2}\right)$. In addition, $\mathrm{H}_{2} \mathrm{SO}_{4}$ exhibited greater aggressive properties, hence decreased more significantly.

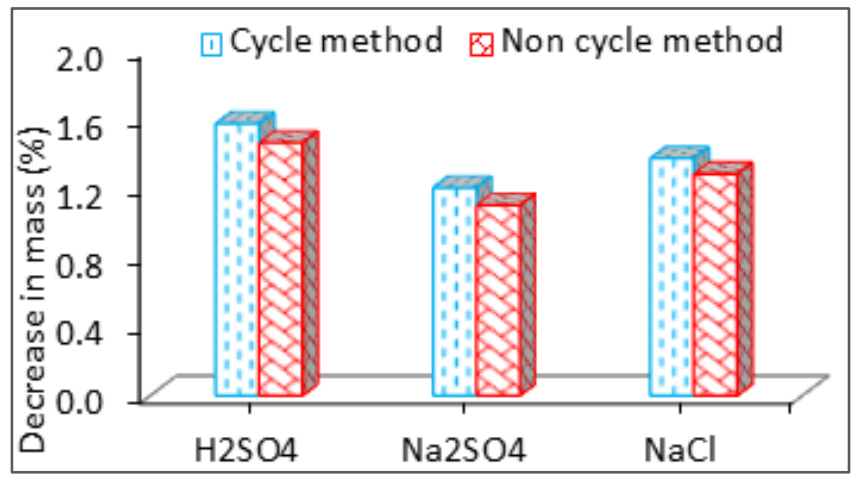

Fig 5:- Percentage of decrease in mortar mass

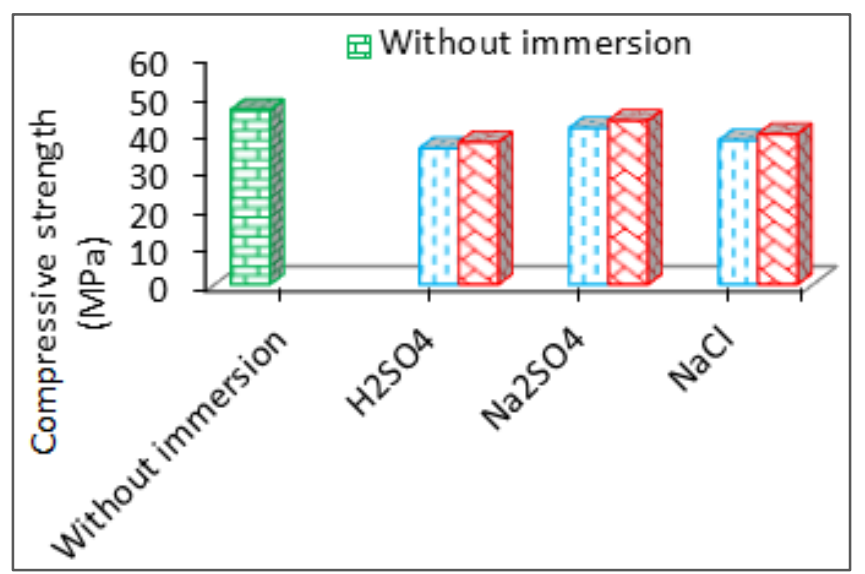

Fig 6:- Decrease in compressive strength of mortar.

\section{Microstructure}

Figure 7 shows the result of Scanning Electron Microscope (SEM) evaluation, performed to determine the geopolymer mortar microstructure experiencing strength degradation. In addition, the materials without immersion comprised a dense and fairly smooth surface with several scattered pores. However, attacks by sulfate and chloride solutions led to the incidence of surface damage, characterized by significant pore and crack formation on the layers as the reaction proceeds. Similarly, the wet-dry cycle method produced a non-dense geopolymer matrix, featuring larger pores and cracks. This phenomenon was implicated in the degradation of compressive strength and mass observed with the mortar.

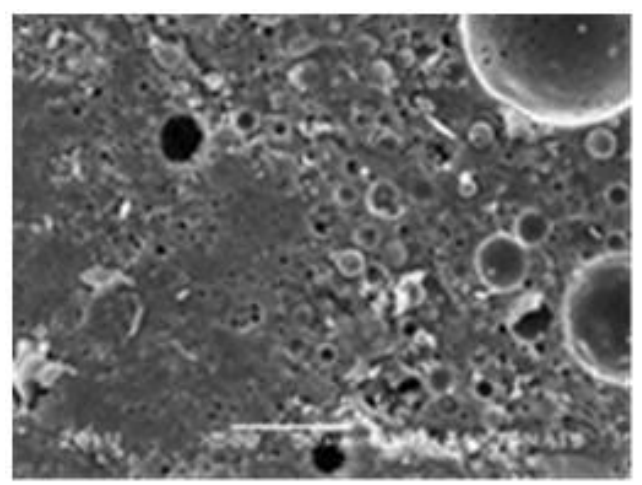

(a) 28 days without immersion

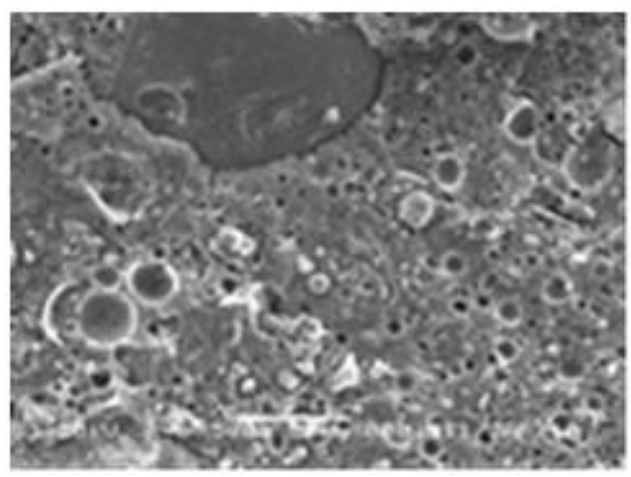

(b) 28 days of $5 \% \mathrm{Na}_{2} \mathrm{SO}_{4}$ immersion by the wet-dry non cycle method

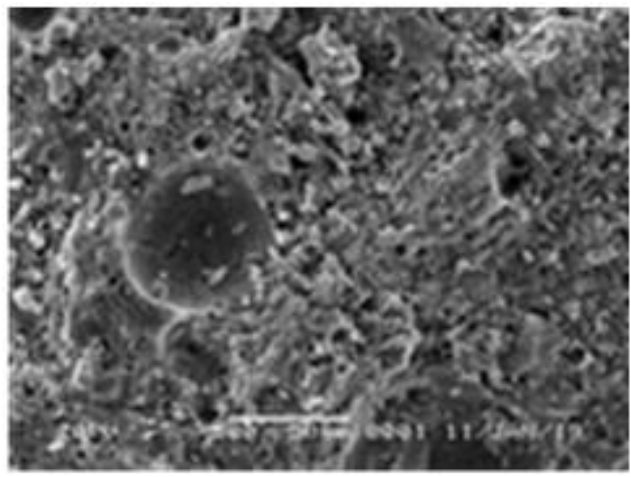

(c) 28 days of $5 \% \mathrm{Na}_{2} \mathrm{SO}_{4}$ immersion by the wet-dry cycle method

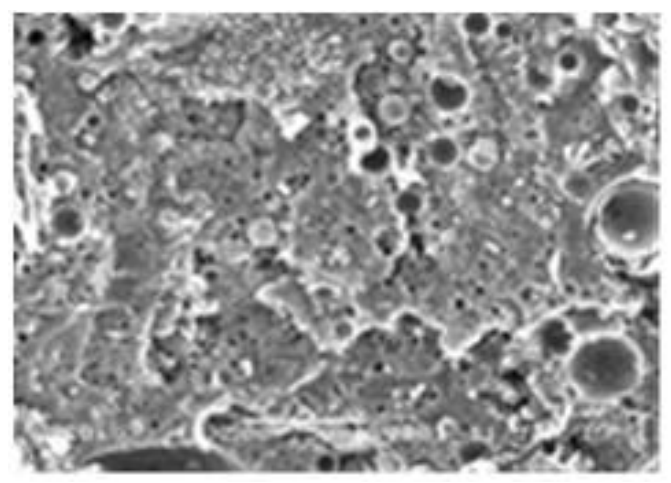

(d) 28 days of $5 \% \mathrm{NaCl}$ immersion by the wet-dry non cycle method 


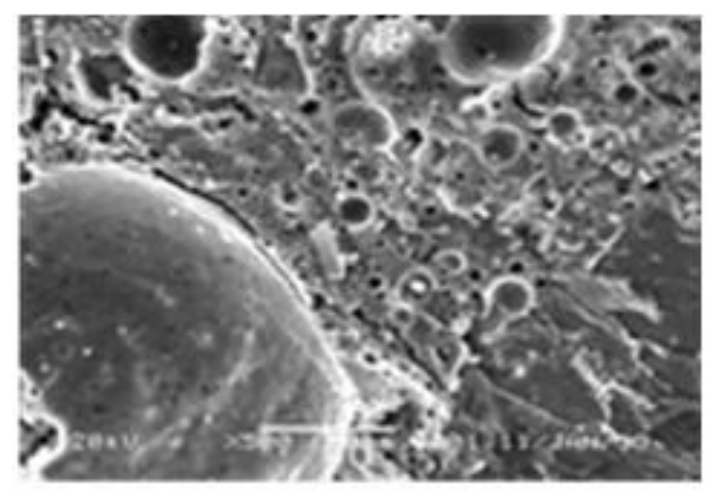

(e) 28 days of $5 \% \mathrm{NaCl}$ immersion by the wet-dry cycle method

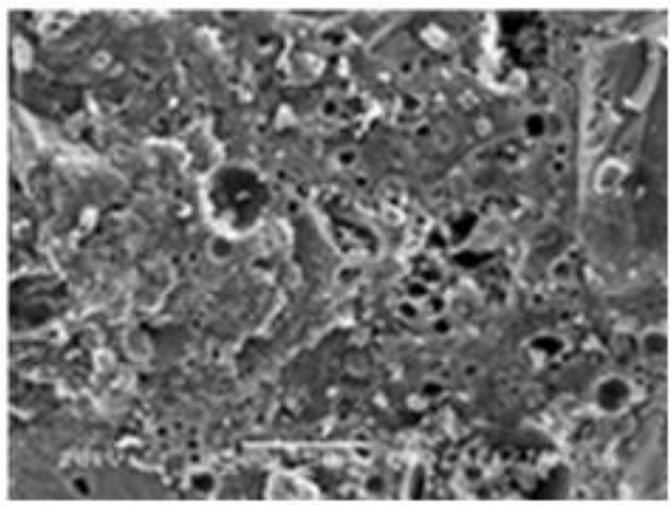

(f) 28 days of $5 \% \mathrm{H} 2 \mathrm{SO} 4$ immersion by the wet-dry non cycle method

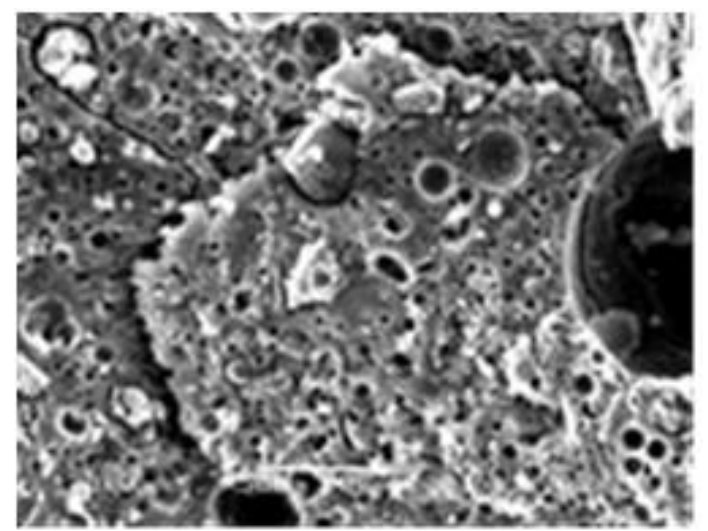

(g) 28 days of $5 \%$ H2SO4 immersion by the wet-dry cycle method

Fig 7:- Microstructure.

\section{CONCLUSION}

Based on the research on fly ash-based geopolymer mortar, the following conclusions, the slump flow diameter of geopolymer mortar of $13.50 \mathrm{~cm}$ indicates good workability. Initial and final setting time take 66.43 and 105 minutes respectively, signifying a rapid polymerization process. Cyclic and non-cyclic methods were explored in testing durability. The decrease in mass of mortar immersed in $\mathrm{H}_{2} \mathrm{SO}_{4}, \mathrm{Na}_{2} \mathrm{SO}_{4}$ and $\mathrm{NaCl}$ solutions was $1.57 \% ; 1.20 \%$ and $1.37 \%$ for the wet-dry cycle; while $1.46 \% ; 1.10 \%$ and $1.28 \%$ were obtained for the wet-dry non cycle procedure. Meanwhile, the decrease in compressive strength of geopolymer mortars dipped in $\mathrm{H}_{2} \mathrm{SO}_{4}, \mathrm{Na}_{2} \mathrm{SO}_{4}$ and $\mathrm{NaCl}$ were $22.03 \%, 10.48 \%$ and $17.54 \%$ for the wet-dry cycle method, while $18.61 \% ; 6.21 \%$ and $13.90 \%$ were observed for the wet-dry non cycle respectively. SEM test results proved a 28-day geopolymer mortar, without immersion, has a dense and fairly smooth surface with several scattered pores. Meanwhile, mortar immersed for similar interval by wet-dry cycle and non-cycle methods, produced a nondense geopolymer matrix, with the pores and crack getting bigger.

\section{ACKNOWLEDGMENT}

The research presented in this paper was supported by a grant from Unggulan Kompetitif Universitas Sriwijaya 2018 and PT. Semen Baturaja.

\section{REFERENCES}

[1]. S. Kumaravel and K. Girija, "Acid and salt resistance of geopolymer concrete with varying concentration of $\mathrm{NaOH}, "$ Journal of Engineering Research and Studies, 2013.

[2]. J. Davidovits, "Chemistry of geopolymer system, terminology," Paper presented at the Geopolymer International Conference, Saint Quentin, France, 1994.

[3]. Saloma, Hanafiah, D. O. Elysandi and D. G. Meykan, "Effect of $\mathrm{Na}_{2} \mathrm{SiO}_{3} / \mathrm{NaOH}$ on Mechanical Properties and Microstructure of Geopolymer Mortar Using Fly Ash and Rice Husk Ash as Precursor," AIP Conference Proceedings, 1903, 050013, 2017.

[4]. S. H. Sanni and R. B. Khadiranaikar, "Performance of Alkaline Solutions on Grades of Geopolymer Concrete," International Journal of Research in Engineering and Technology, pp. 366-371, 2013.

[5]. N. Singh, S. Vyas, R. P. Pathak, P. Sharma, N. V. Mahure, S.L. Gupta, "Effect of Aggressive Chemical Environment on Durability of Green Geopolymer Concrete," International Journal of Engineering and Innovative Technology, 3(4), pp. 277-284, 2013.

[6]. C. Kumar, K. Murari, and C. R. Sharma, "Performance of Geopolymer Concrete at Elevated Temperature and Against Aggressive Chemical Environment," Internationl Journal of Innovative Research in Science, Engineering and Technology, 3(6), 2014, pp. 13366-13373.

[7]. D. Wiyono, Antoni and D. Hardjito, "Improving the durability of pozzolan concrete using alkaline solution and geopolymer coating," Procedia Engineering, 125, pp. 747 - 753, 2015.

[8]. J. Davidovits, 30 Years of Successes and Failures in Geopolymer Applications, Market Trends and Potential Breakthroughs, in: Proceeding of Keynote Conference on Geopolymer Conference, Melbourne, 2002. 